\title{
Gliotoxin from the marine fungus Aspergillus fumigatus induces apoptosis in HT1080 fibrosarcoma cells by downregulating NF-KB
}

\author{
Young-Sang Kim and Sun Joo Park
}

\begin{abstract}
Gliotoxin has been recognized as an immunosuppressive agent for a long time. Recently, it was reported to have antitumor properties. However, the mechanisms by which it inhibits tumors remain unclear. Here, we showed that gliotoxin isolated from the marine fungus Aspergillus fumigatus inhibited proliferation and induced apoptosis in HT1080 human fibrosarcoma cells. Gliotoxin repressed phosphorylation-dependent degradation of IkB-a, an antagonist of nuclear factor kappa B (NF-kB), which is a known tumor-promoting factor. This coincided with a decrease in nuclear import of NF-KB, suggesting its signaling activity was impaired. Moreover, gliotoxin increased intracellular reactive oxygen species (ROS). Since ROS have been known to inhibit NF-kB, this may also contribute to gliotoxin's antitumorigenic effects. These results suggest that gliotoxin suppressed the activation of NF-kB by inhibiting phosphorylation and degradation of $1 \mathrm{~KB}-\mathrm{a}$ and by increasing ROS, which resulted in apoptosis of HT1080 cells. Cumulatively, gliotoxin is a promising candidate antagonist of NF-kB , and it should be investigated for its possible use as a selective inhibitor of human fibrosarcoma cells.
\end{abstract}

Keywords: Gliotoxin, Marine fungus, Aspergillus fumigatus, Apoptosis, HT1080 cells

\section{Background}

Fungal secondary metabolites are chemically diverse, and some display pharmaceutical potential as inhibitors of inflammation, cytotoxicity, and cancer (Shao et al. 2011; Wei et al. 2010). Gliotoxin, a member of the epipolythiodioxopiperazine family of secondary metabolites, is characterized by a disulfide bond across a piperazine ring. It has been isolated from several species of fungi, including the human pathogen Aspergillus (Waring et al. 1995). Gliotoxin is known to possess immunosuppressive properties, and it causes apoptosis in immune cells including neutrophils, eosinophils, macrophages, and thymocytes (Sutton et al. 1994; Pahl et al. 1996; Lopez-Franco et al. 2002). Gliotoxin's immunosuppressive properties result from its inhibition of nuclear factor kappa B (NF-kB) because it represses proteasomemediated degradation of the NF- $\mathrm{kB}$ antagonist, IкB- $\alpha$

\footnotetext{
* Correspondence: parksj@pknu.ac.kr

Department of Chemistry, Pukyong National University, Busan 608-737, Republic of Korea
}

(Kroll et al. 1999; Lopez-Franco et al. 2002). Gliotoxin also enters the redox cycle and transitions between reduced and oxidized forms after uptake into cells. Reactive oxygen species (ROS) are produced as a by-product, and this induces DNA damage and apoptosis in immune cells (Harms et al. 2015). ROS have also been reported to inhibit NF- $\mathrm{kB}$ through direct oxidation (Toledano and Leonard 1991; Nowak et al. 2008). In this regard, the role of gliotoxin in regulating $N F-\kappa B$ and ROS has focused on immunological therapeutic applications. However, recent publications suggest that gliotoxin has antitumor properties (Kweon et al. 2003; Bhatnagar and Kim 2015), although the mechanistic details remain unclear. In the present study, we investigated the antiproliferative effects of gliotoxin on HT1080 human fibrosarcoma cells. We found that gliotoxin from the marine fungus Aspergillus fumigatu regulates proliferation of HT1080 cells by inducing apoptosis. This cytotoxicity was related to the inactivation of NF- $\kappa B$ and an increase in intracellular ROS. 


\section{Methods}

\section{Materials and chemicals}

Gliotoxin from the marine fungus Aspergillus fumigatus was obtained as described by Bhatnagar and Kim (2015). Briefly, A. fumigatus was isolated from the surface of marine green algae, which were collected in Cheongsapo, Busan, Republic of Korea. The fungal strain was cultured in YPGA media containing $0.1 \%$ yeast extract, $2 \%$ peptone, $1 \%$ glucose, $2 \%$ agar, $60 \%$ seawater, and $40 \%$ distilled water. The fermentation broth was extracted $(2.3 \mathrm{~g})$ with ethyl acetate (EtOAc, 1:1.5 $v / v$; broth-EtOAc, 1:1 $v / v)$. The extract was fractionated by silica gel chromatography (n-hexane-EtOAc, $100 \%: 0 \%$; $\mathrm{CH}_{2} \mathrm{Cl}_{2}$-methyl alcohol $(\mathrm{MeOH}), 1: 1)$, ODS column chromatography $\left(\mathrm{H}_{2} \mathrm{O}-\mathrm{MeOH}, 100 \%: 100 \%\right)$, and Sephadex LH-20 column chromatography $\left(\mathrm{H}_{2} \mathrm{O}-\mathrm{MeOH}, 100\right.$ \%:100 \%). Highperformance liquid chromatography (HPLC) using a YMC ODS-A column $(250 \mathrm{~mm} \times 10 \mathrm{~mm}$ I.D., S-5 $\mu \mathrm{m}, 12 \mathrm{~nm}$, $\mathrm{MeOH})$ yielded purified gliotoxin $(5.2 \mathrm{mg})$. The structure and molecular formula of gliotoxin was ascertained using ${ }^{1} \mathrm{H}$ and ${ }^{13} \mathrm{C}$ nuclear magnetic resonance (NMR), as well as low-resolution electron impact mass spectrometry (LREI-MS) data. ${ }^{1} \mathrm{H}$ NMR spectrum (DMSO- $\mathrm{d}_{6}$, $400 \mathrm{MHz}): 3.44(1 \mathrm{H}, \mathrm{dd}, J=4.8, \mathrm{H}-3 \mathrm{a}), 4.28(1 \mathrm{H}, \mathrm{dd}, J=$ 9.9, H-3a), 4.39 (1H, dd, J=6.8, H-5), $4.842(1 \mathrm{H}, \mathrm{m}$, H-6), 5.78 (1H, d, J=9.9, H-7), 5.95 (1H, m, H-8), 6.00 (1H, m, H-9), 2.96, 3,73 (1H, d, J=18.1, H-10), 3.20 (3H, s, H-11). ${ }^{13} \mathrm{C}$ NMR spectrum (DMSO- $d_{6}, 100 \mathrm{MHz}$ ): 166.0 (C-1), 77.2 (C-3), 60.5 (C-3), 165.2 (C-4), 69.8 (C-5), 75.6 (C-6), 129.9 (C-7), 123.4 (C-8), 120.2 (C-9), 130.7 (C-19a), 36.6 (C-10), 73.1 (C-10a), 27.5 (C-11). LREI-MS $m / z: 349[\mathrm{M}]^{+}\left(\mathrm{C}_{21} \mathrm{H}_{23} \mathrm{~N}_{3} \mathrm{O}_{2}\right)$. LREI-MS $m / z: 326.38[\mathrm{M}]^{+}$ $\left(\mathrm{C}_{13} \mathrm{H}_{14} \mathrm{~N}_{2} \mathrm{O}_{4} \mathrm{~S}_{2}\right)$.

Human fibrosarcoma cells (HT1080) were obtained from the Korean Cell Line Bank (KCLB, Seoul, Korea). Cells were cultured in DMEM supplemented with penicillin/streptomycin and fetal bovine serum (FBS) (Gibco BRL, Life Technology, NY, USA). Cytotoxicity assays were performed with 3-(4,5-dimethyl-2-yl)-2,5-diphenyltetrazolium bromide (MTT) reagent (Sigma Chemical Co., St. Louis, MO, USA). All antibodies used for western blot analysis were purchased from Santa Cruz Biotechnology, Inc. (Santa Cruz, CA, USA). Other chemicals and reagents were of commercially available analytical grade.

\section{Cell culture and cell viability assay}

HT1080 cells were cultured on DMEM (Gibco, USA) containing $10 \% \mathrm{FBS}$ and incubated at $37{ }^{\circ} \mathrm{C}$ under a humidified atmosphere of $5 \% \mathrm{CO}_{2}$. Cytotoxicity of gliotoxin on HT1080 cells was analyzed using an MTT assay. To estimate the cytotoxicity of gliotoxin, cells were seeded in a 96-well plate at a concentration of $4 \times$ $10^{4}$ cells $/ \mathrm{ml}$ and incubated for $24 \mathrm{~h}$. The cells were then exposed to different concentrations $(0,25,50$, or $100 \mu \mathrm{M}$ ) of gliotoxin at $37^{\circ} \mathrm{C}$ under a humidified atmosphere of $5 \% \mathrm{CO}_{2}$. Subsequently, $100 \mu \mathrm{l}$ MTT solution $(1 \mathrm{mg} / \mathrm{ml})$ was added to each well, and cells were incubated for another $3 \mathrm{~h}$. The formazan salt that formed was dissolved in $100 \mu \mathrm{l}$ DMSO. The absorbance was measured at $550 \mathrm{~nm}$ (GENiosr Microplate Reader, Tecan Austria GmbH, Austria).

\section{Annexin V/propidium iodide (PI) assay}

Apoptotic cells were stained using the fluorescence isothiocyanate (FITC) Annexin V apoptosis detection kit (BD Biosciences) according to the manufacturer's instructions. Briefly, HT1080 cells were cultured in 6 -well plates at a density of $5 \times 10^{4}$ cells $/ \mathrm{ml}$. The cells were then treated with $100 \mu \mathrm{M}$ gliotoxin for $24 \mathrm{~h}$. After incubation, trypsinized, floating, and adherent cells were pooled and centrifuged. Harvested cells were washed with PBS twice, mixed in $1 \times$ binding buffer, and incubated with Annexin V/PI double-staining solution at room temperature (RT) for $20 \mathrm{~min}$. The stained cells were analyzed by flow cytometry (FACSCalibur, BD Science, Heidelberg, Germany), and the percentage of apoptotic cells was calculated using Cell Quest software.

\section{Extraction of cellular proteins}

After the indicated incubation times with or without $100 \mu \mathrm{M}$ gliotoxin, HT1080 cells were lysed. Nuclear and cytoplasmic extracts were prepared according to Duvoix et al. (2004). Briefly, cell pellets were suspended in icecold hypotonic lysis buffer containing protease inhibitors. We added $10 \%$ Igepal (Sigma-Aldrich) to the cell suspension and vortexed for $10 \mathrm{~s}$ to lyse the cells. The lysate was then centrifuged at $18,000 \mathrm{rpm}$ for $1 \mathrm{~min}$. The cytoplasmic supernatant was stored, and cell pellets were washed with hypotonic lysis buffer. Nuclear extraction buffer was added to each pellet, and the cell suspension was gently mixed on an orbital shaker for $15 \mathrm{~min}$ at $4{ }^{\circ} \mathrm{C}$. This was followed by centrifugation at $10,500 \mathrm{rpm}$ for $7 \mathrm{~min}$ at $4{ }^{\circ} \mathrm{C}$. Finally, the nuclear supernatant was transferred to a prechilled microcentrifuge tube and stored at $-80{ }^{\circ} \mathrm{C}$.

\section{Western blot analysis}

Western blotting was performed according to the standard procedures. Briefly, cells were cultured at a density of $5 \times 10^{4}$ cells $/ \mathrm{ml}$ in six-well plates with serum-free media. After incubation for $24 \mathrm{~h}$, cells were treated with gliotoxin for another $24 \mathrm{~h}$. Cells were lysed in RIPA $\left(150 \mathrm{mM} \mathrm{NaCl}, 1.0 \%\right.$ IGEPAL $^{\oplus} 0.5 \%$ sodium deoxycholate, $0.1 \%$ sodium dodecylsulfate, $50 \mathrm{mM}$ Tris, $\mathrm{pH} 8.0$ ) buffer at $4{ }^{\circ} \mathrm{C}$ for $30 \mathrm{~min}$. Proteins from nuclear and cytoplasmic extracts were obtained, and $100 \mu \mathrm{g} / \mathrm{ml}$ of 
protein was separated using $10 \%$ sodium dodecyl sulfate-polyacrylamide gel electrophoresis with a $5 \%$ stacking gel. Separated proteins were transferred onto a nitrocellulose membrane (Amersham Pharmacia Biotech, England, UK). The membrane was blocked for $1.5 \mathrm{~h}$ at RT using Tris-buffered saline and $0.1 \%$ Tween-20 (TBS-T) with $5 \%$ skim milk. After washing the membrane with TBS-T twice, the blots were incubated for $1 \mathrm{~h}$ with the indicated antibodies at $25{ }^{\circ} \mathrm{C}$. The respective proteins were detected with a chemiluminescent ECL assay kit (Amersham Pharmacia, England, UK) according to the manufacturer's instructions.

\section{Measurement of ROS}

HT1080 cells $\left(2 \times 10^{5}\right.$ cells $)$ were incubated with or without $100 \mu \mathrm{M}$ gliotoxin for $24 \mathrm{~h}$. Cellular ROS levels were determined by staining with dihydroethidium (DHE) (SigmaAldrich) and by using the Muse Oxidative Stress Kit (Millipore) according to the manufacturer's instructions.

\section{Statistical analysis}

Data were analyzed using the InStat statistics program (GraphPad Software, Inc., San Diego, CA, USA). Statistical comparisons were performed using one-way analysis of variance (ANOVA) with the Bonferroni test for multiple comparisons.

\section{Results}

To examine the antiproliferative effects of gliotoxin on human HT1080 fibrosarcoma cells, we treated cultures with various concentrations of gliotoxin $(0-100 \mu \mathrm{M})$ for $24 \mathrm{~h}$. The antiproliferative effects were assessed by a colorimetric MTT assay. Gliotoxin treatment decreased the number of viable cells in a dose-dependent manner (Fig. 1). This suggested that gliotoxin decreased proliferation of HT1080 cells, and it may have generally cytotoxic effects.

To determine whether the antiproliferative effect of gliotoxin was associated with apoptotic cell death, HT1080 cells were treated with $100 \mu \mathrm{M}$ gliotoxin for $24 \mathrm{~h}$. Cells were then double stained with Annexin V and propidium iodide (PI), and flow cytometric analyses were performed (Fig. 2). The percentage of Annexin Vpositive and PI-positive cells presenting in late-apoptosis phase increased from 33.7 to $68.7 \%$ after treatment with gliotoxin. This clearly indicates that gliotoxin induced apoptosis in HT1080 cells.

$N F-\kappa B$ induces expression of several genes that promote malignant properties associated with tumor growth and inhibit apoptosis (Panwalkar et al. 2004). Constitutive activation of NF-kB has been shown in several types of cancer (Sasaki et al. 2001; Weichert et al. 2007; Sakamoto et al. 2009). In unstimulated cells, $\mathrm{NF}-\mathrm{kB}$ is typically sequestered in the cytoplasm where

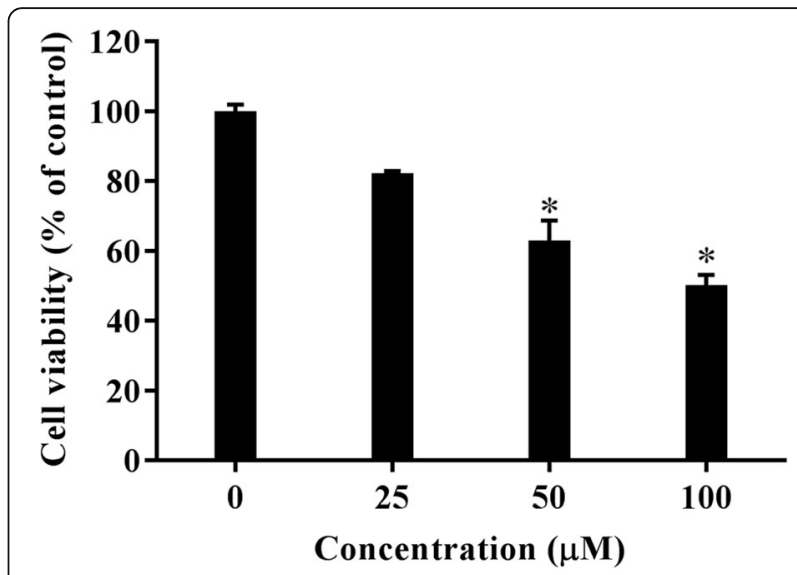

Fig. 1 Gliotoxin decreases proliferation of HT1080 human fibrosarcoma cells. HT1080 cells were treated with various concentrations (0 to $100 \mu \mathrm{M}$ ) of gliotoxin for $24 \mathrm{~h}$. Cell viability was determined by MTT assay. Each value is expressed as the mean \pm standard deviation (SD) of three independent experiments. ${ }^{*} P<0.05$ compared to the control group $(0 \mu \mathrm{M})$

it complexes with inhibitors such as ІкB- $\alpha$. When cells experience the proper stimulus, cytoplasmic NF- $\mathrm{kB}$ becomes activated primarily through phosphorylation and degradation of I $\mathrm{kB}-\alpha$. NF- $\mathrm{kB}$ then translocates from the cytosol to the nucleus and induces expression of target genes (Siebenlist et al. 1994; Baeuerle and Baltimore 1996).

To examine the effects of gliotoxin on NF- $\mathrm{BB}$ signaling, we analyzed the expression and phosphorylation state of IкB- $\alpha$. We also investigated the expression of $\mathrm{NF}-\mathrm{kB}$ and the nuclear translocation dynamics of the p65 subunit after gliotoxin treatment (Fig. 3). HT1080 cells were cultured with gliotoxin $(0-100 \mu \mathrm{M})$ for $24 \mathrm{~h}$, and the cytosol and nuclear lysates were each subjected to western blot analysis. Treatment with gliotoxin inhibited NF-kB activation. High levels of NF-kB-p65 were found in nuclear fraction of control HT1080 cells without gliotoxin treatment. However, exposure to gliotoxin decreased the amount of nuclear-localized NF-kB-p65. Gliotoxin treatment also reduced phosphorylation of ІкB- $\alpha$ and increased overall expression of IкB- $\alpha$. Together, these results suggest that gliotoxin inhibited the nuclear import and activation of NF- $\mathrm{KB}$ by suppressing the phosphorylation and subsequent degradation of its inhibitor, IKB- $\alpha$.

ROS are produced by a variety of cellular processes. This oxidative stress response frequently triggers apoptotic cell death (Russell and cotter 2015). One reason for this is the inhibition of NF- $\mathrm{KB}$ activity by ROS, which ultimately enhances apoptosis. Specifically, ROS inhibit DNA binding of NF- $\mathrm{kB}$ through direct oxidation of NF- $\mathrm{kB}$ (Toledano and Leonard 1991; Nowak et al. 2008) and through the modification of its inhibitor, 


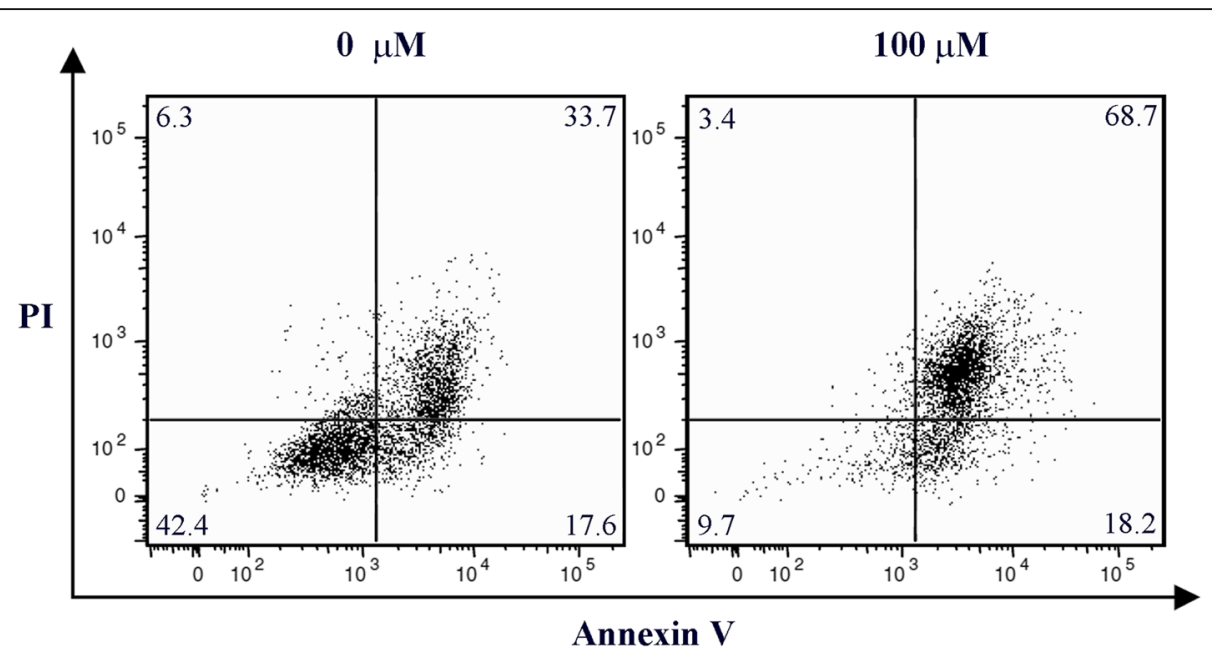

Fig. 2 Gliotoxin induces apoptosis of HT1080 cells. HT1080 cells were treated with $100 \mu \mathrm{M}$ gliotoxin for $24 \mathrm{~h}$ and analyzed by Annexin V/PI staining. Gliotoxin increased the cell population occupying the Annexin V/PI double-positive quadrant (UR upper right), which represents late-apoptotic cells

IкB- $\alpha$. Therefore, we examined whether gliotoxin influenced ROS levels in HT1080 cells. After treating cells with $100 \mu \mathrm{M}$ gliotoxin, ROS levels increased from 32.2 to $62.7 \%$ compared to untreated controls (Fig. 4). Taken together, these results suggest that gliotoxin triggered apoptotic cell death in HT1080 cells via generation of ROS and inactivation of NF- $\mathrm{KB}$ signaling.

\section{Discussion}

Apoptosis is a process of programmed cell death that occurs in multicellular organisms. The development and progression of cancer frequently involves the suppression of apoptosis. Therefore, almost all cytotoxic anticancer therapies currently in clinical use attempt to target cancer cells by inducing apoptosis. The NF-kB pathway is involved in tumorigenesis, tumor cell proliferation, and

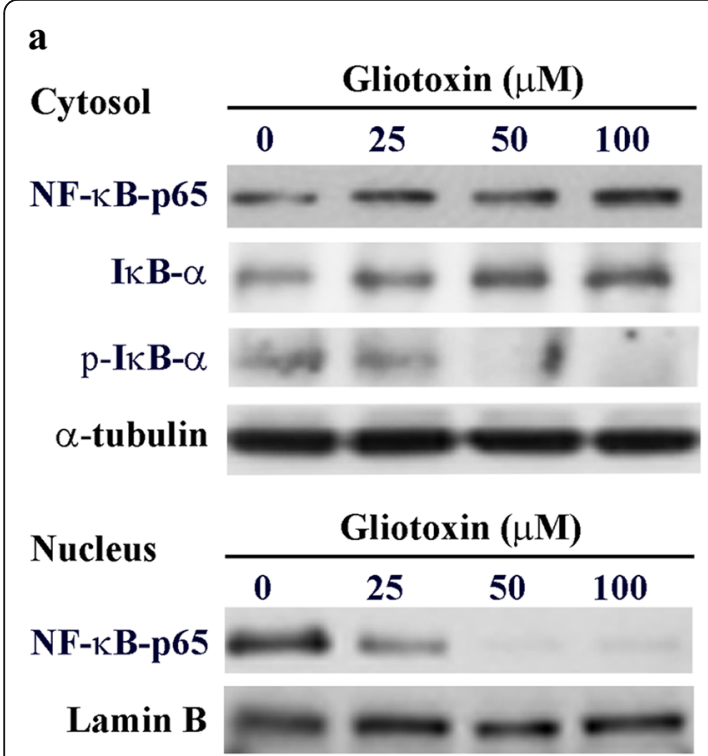

b

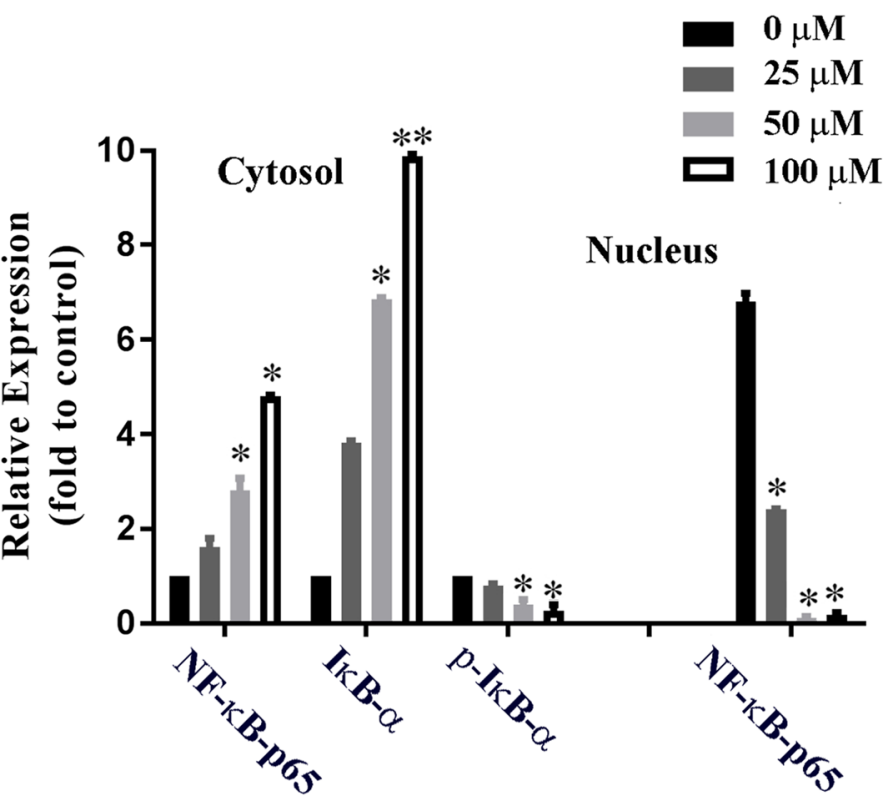

Fig. 3 Gliotoxin inhibits activation of NF-KB by suppressing the phosphorylation and degradation of IKB-a. HT1080 cells were treated with various concentrations ( 0 to $100 \mu \mathrm{M}$ ) of gliotoxin for $24 \mathrm{~h}$, and the cytosol and nuclear lysates were subjected to immunostaining for the p65 subunit of NF-KB, phosphorylated IKB-a, total IKB-a, a-tubulin, and lamin B (a). The immunoblot signals were quantified. Each value was expressed as the mean \pm SD of a triplicate experiment. ${ }^{*} P<0.05$ compared to the control without gliotoxin treatment (b) 


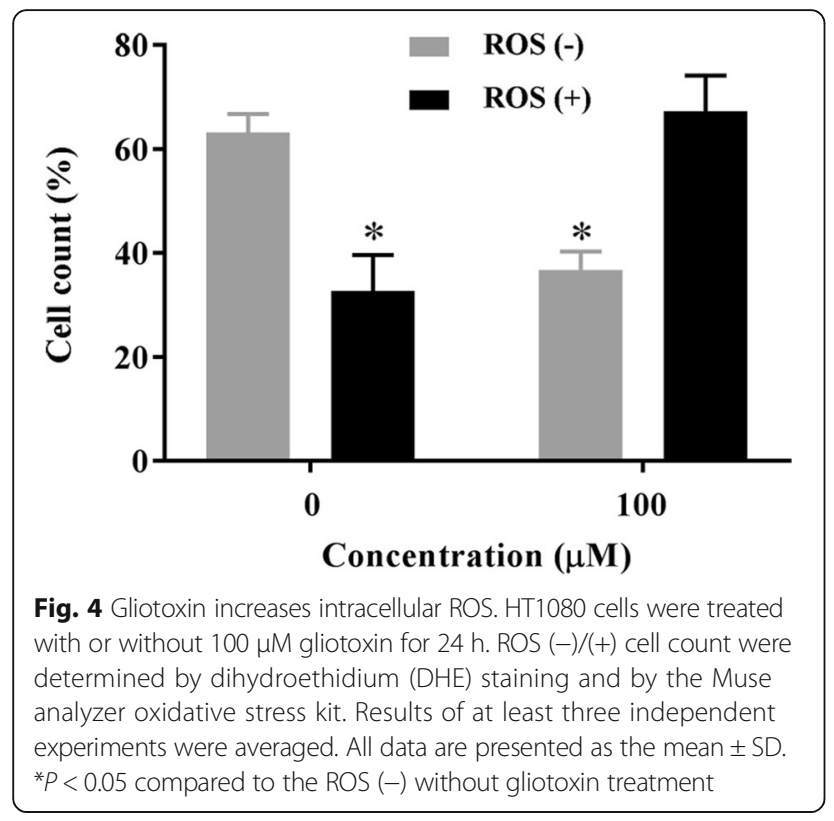

apoptosis, as well as cellular immunity and inflammation. For example, constitutive activation of NF- $\mathrm{kB}$ has been reported in several types of cancers including gastric cancer, pancreatic cancer, and colorectal carcinoma (Sasaki et al. 2001; Weichert et al. 2007; Sakamoto et al. 2009). NF-kB helps activate downstream proteins that promote tumor growth and inhibit apoptosis in tumor cells. Given the antiapoptotic effects of NF-kB, inhibitors of NF- $\mathrm{KB}$ are promising antitumor drugs. As a result, much effort has focused on developing inhibitors that target NF-kB (Yemelyanov et al. 2006; Yang et al. 2006). Recently, ROS have been also reported to repress NF- $\mathrm{kB}$ signaling in many ways. Direct oxidation of NF$\kappa \mathrm{B}$ by ROS inhibits its DNA-binding ability (Toledano and Leonard 1991). ROS modification of IкB- $\alpha$ leads to inhibition of NF-kB signaling (Nowak et al. 2008). In addition, ROS stabilize IkB- $\alpha$ by inhibiting the proteasome, resulting in downregulation of NF- $\mathrm{kB}$ signaling (Wu et al. 2009). Therefore, it seems reasonable that ROS function as physiological signaling modulators of NF- $\kappa$ B signaling cascades in cancers. Our results support this hypothesis. We showed that gliotoxin, a natural compound isolated from the marine fungus A. fumigatus, inhibited proliferation and induced apoptosis in human HT1080 fibrosarcoma cells by increasing intracellular ROS levels and repressing activation and nuclear translocation of NF- $\mathrm{kB}$. Therefore, we suggest that gliotoxin may constitute a promising new antitumor drug for the targeted inhibition of NF-kB signaling.

\section{Conclusions}

We demonstrated that gliotoxin, a mycotoxin produced by the marine fungus $A$. fumigatus, induced apoptosis in
HT1080 human fibrosarcoma cells. It achieved this, at least in part, through an increase in levels of intracellular ROS and repression of NF-kB signaling. Cumulatively, our results provide a new avenue of research into the design and development of NF- $\mathrm{BB}$ antagonists for the treatment of cancer.

\section{Abbreviations}

DHE: Dihydroethidium; EtOAc: Ethyl acetate; FBS: Fetal bovine serum; HPLC: High-performance liquid chromatography; KCLB: Korean Cell Line Bank; LREI-MS: Low-resolution electron impact mass spectrometry; MeOH: Methyl alcohol; MTT: 3-(4,5-Dimethyl-2-yl)-2,5-diphenyltetrazolium bromide; NF-kB: Nuclear factor kappa B; NMR: Nuclear magnetic resonance; PI: Propidium iodide; ROS: Reactive oxygen species; RT: Room temperature

\section{Acknowledgements}

This work was supported by a Research Grant of Pukyong National University (2016).

\section{Funding}

This study was funded by a grant from the Pukyong National University (2016).

Availability of data and materials

All datasets generated during and/or analyzed during the current study are available from the corresponding author on reasonable request.

\section{Authors' contributions}

YSK designed and carried out the experiments. SJP interpreted the results and wrote the manuscript. Both authors read and approved the final manuscript.

\section{Competing interests}

The authors declare that they have no competing interests.

\section{Consent for publication}

Not applicable.

Ethics approval and consent to participate Not applicable.

Received: 23 August 2016 Accepted: 21 October 2016

Published online: 04 November 2016

\section{References}

Baeuerle PA, Baltimore D. NF-kappa B: ten years after. Cell. 1996;87:13-20.

Bhatnagar I, Kim SK. Gliotoxin from Aspergillus fumigatus reverses epithelial to mesenchymal transition: implications in renal fibrosis. Int J Med Microbiol. 2015:305:11-9.

Duvoix A, Delhalle S, Blasius R, Schnekenburger M, Morceau F, Fougere M, et al. Effect of chemopreventive agents on glutathione S-transferase P1-1 gene expression mechanisms via activating protein 1 and nuclear factor kappaB inhibition. Biochem Pharmacol. 2004;68:1101-11.

Harms H, Orlikova B, Ji S, Nesaei-Mosaferan D, Konig GM, Diederich M. Epipolythiodiketopiperazines from the marine derived fungus Dichotomomyces cejpii with NF-kappaB inhibitory potential. Mar Drugs. 2015;13:4949-66.

Kroll M, Arenzana-Seisdedos F, Bachelerie F, Thomas D, Friguet B, Conconi M. The secondary fungal metabolite gliotoxin targets proteolytic activities of the proteasome. Chem Biol. 1999;6:689-98.

Kweon YO, Paik YH, Schnabl B, Oian T, Lemasters JJ, Brenner DA. Gliotoxinmediated apoptosis of activated human hepatic stellate cells. J Hepatol. 2003:39:38-46.

Lopez-Franco O, Suzuki Y, Sanjuan G, Blanco J, Hernandez-Vargas P, Yo Y, et al. Nuclear factor-kappa B inhibitors as potential novel anti-inflammatory agents for the treatment of immune glomerulonephritis. Am J Pathol. 2002;161:1497-505.

Nowak DE, Tian B, Jamaluddin M, Boldogh I, Vergara LA, Choudhary S, et al. RelA Ser276 phosphorylation is required for activation of a subset of NF-kappaBdependent genes by recruiting cyclin-dependent kinase 9/cyclin T1 complexes. Mol Cell Biol. 2008:28:3623-38.

Pahl HL, Krauss B, Schulze-Osthoff K, Decker T, Traenckner EB, Vogt M, et al. The immunosuppressive fungal metabolite gliotoxin specifically inhibits transcription factor NF-kappaB. J Exp Med. 1996;183:1829-40. 
Panwalkar A, Verstovsek S, Giles F. Nuclear factor-kappaB modulation as a therapeutic approach in hematologic malignancies. Cancer. 2004;100:1578-89.

Russell EG, Cotter TG. New insight into the role of reactive oxygen species (ROS) in cellular signal-transduction processes. Int Rev Cell Mol Biol. 2015;319:221-54.

Sakamoto K, Maeda S, Hikiba Y, Nakagawa H, Hayakawa Y, Shibata W, et al. Constitutive NF-kappaB activation in colorectal carcinoma plays a key role in angiogenesis, promoting tumor growth. Clin Cancer Res. 2009;15:2248-58.

Sasaki N, Morisaki T, Hashizume K, Yao T, Tsuneyoshi M, Noshiro H, et al. Nuclear factor-kappaB p65 (RelA) transcription factor is constitutively activated in human gastric carcinoma tissue. Clin Cancer Res. 2001;7:4136-42.

Shao CL, Wang CY, Wei MY, Gu YC, She ZG, Qian PY, et al. Aspergilones A and B, two benzylazaphilones with an unprecedented carbon skeleton from the gorgonianderived fungus Aspergillus sp. Bioorg Med Chem Lett. 2011;21:690-3.

Siebenlist U, Franzoso G, Brown K. Structure, regulation and function of NF-kappa B. Annu Rev Cell Biol. 1994;10:405-55.

Sutton P, Newcombe NR, Waring P, Mullbacher A. In vivo immunosuppressive activity of gliotoxin, a metabolite produced by human pathogenic fungi. Infect Immun. 1994;62:1192-8.

Toledano MB, Leonard WJ. Modulation of transcription factor NF-kappa B binding activity by oxidation-reduction in vitro. Proc Natl Acad Sci U S A. 1991;88: 4328-32.

Waring P, Sjaarda A, Lin QH. Gliotoxin inactivates alcohol dehydrogenase by either covalent modification or free radical damage mediated by redox cycling. Biochem Pharmacol. 1995;49:1195-201.

Wei MY, Wang CY, Liu QA, Shao CL, She ZG, Lin YC. Five sesquiterpenoids from a marine-derived fungus Aspergillus sp. isolated from a gorgonian Dichotella gemmacea. Mar Drugs. 2010;8:941-9.

Weichert W, Boehm M, Gekeler V, Bahra M, Langrehr J, Neuhaus P, et al. High expression of RelA/p65 is associated with activation of nuclear factor-kappaBdependent signaling in pancreatic cancer and marks a patient population with poor prognosis. Br J Cancer. 2007;97:523-30.

Wu CH, Wu CF, Huang HW, Jao YC, Yen GC. Naturally occurring flavonoids attenuate high glucose-induced expression of proinflammatory cytokines in human monocytic THP-1 cells. Mol Nutr Food Res. 2009;53:984-95.

Yang $X H$, Li Y, Wang ZL. Expression and significance of toll like receptor 4 mRNA and nuclear factor-kappaB p50 mRNA in human normal nasal mucosa after stimulation by lipopolysaccharide. Zhonghua Er Bi Yan Hou Tou Jing Wai Ke Za Zhi. 2006;41:698-701

Yemelyanov A, Gasparian A, Lindholm P, Dang L, Pierce JW, Kisseljov F, et al. Effects of IKK inhibitor PS1145 on NF-kappaB function, proliferation, apoptosis and invasion activity in prostate carcinoma cells. Oncogene. 2006;25:387-98.

\section{Submit your next manuscript to BioMed Central and we will help you at every step:}

- We accept pre-submission inquiries

- Our selector tool helps you to find the most relevant journal

- We provide round the clock customer support

- Convenient online submission

- Thorough peer review

- Inclusion in PubMed and all major indexing services

- Maximum visibility for your research

Submit your manuscript at www.biomedcentral.com/submit

) Biomed Central 